\title{
PENGARUH DISIPLIN KERJA, MOTIVASI DAN KOMPENSASI TERHADAP KINERJA PERSONIL POLSEK SEMARANG TENGAH KOTA SEMARANG
}

\author{
Joko Rudadi \\ Taofik Hidajat \\ STIE Bank BPD Jateng
}

\begin{abstract}
ABSTRAK
Penelitian ini bertujuan untuk mengetahui dan menganalisis pengaruh disiplin kerja, motivasi dan kompensasi terhadap kinerja personil Polsek Semarang Tengah Kota Semarang. Sampel yang diambil sebanyak 105 personil dari Semarang di Kantor Polsek Semarang Tengah Kota Semarang. Setelah data sampel telah dikumpulkan, data diolah dan dianalisis menggunakan analisis regresi linier berganda dengan menggunakan program komputer IBM SPSS 16. Berdasarkan hasil pengujian hipotesis penelitian dapat disimpulkan variabel disiplin kerja, motivasi, kompensasi berpengaruh positf dan signifikan terhadap kinerja personil Polsek Semarang Tengah Kota Semarang.

Kata Kunci : Disiplin Kerja, Motivasi, Kompensasi, Kinerja Pegawai, dan Kantor Polsek Semarang Tengah Kota Semarang
\end{abstract}

\section{Pendahuluan}

Faktor manusia merupakan masalah utama di kehidupan berorganisasi. Organisasi merupakan kesatuan sosial yang dikoordinasikan secara sadar dengan sebuah batasan yang reaktif dapat diidentifikasikan, bekerja secara terus menerus untuk mencapai tujuan (Robbins, 2006). Semua tindakan yang diambil dalam setiap kegiatan diprakarsai dan ditentukan oleh manusia yang menjadi

anggota organisasi. Organisasi membutuhkan adanya faktor sumber daya manusia yang potensial baik pemimpin maupun personil pada pola tugas dan pengawasan yang merupakan penentu tercapainya tujuan organisasi.

Sumber daya manusia merupakan tokoh sentral dalam organisasi. Agar aktivitas manajemen berjalan dengan baik, organisasi harus memiliki personil yang berpengetahuan dan berketrampilan tinggi serta usaha untuk mengelola organisasi seoptimal mungkin sehingga kinerja personil meningkat. Menurut
Setiyawan dan Waridin (2006) kinerja personil merupakan hasil atau prestasi kerja personil yang dinilai dari segi kualitas maupun kuantitas berdasarkan standar kerja yang ditentukan oleh pihak organisasi. Kinerja yang baik adalah kinerja yang optimal, yaitu kinerja yang sesuai standar organisasi dan mendukung tercapainya tujuan organisasi. Organisasi yang baik adalah organisasi yang berusaha meningkatkan kemampuan sumber daya manusianya, karena hal tersebut merupakan faktor kunci untuk meningkatkan kinerja personil.

Permasalahan kinerja menjadi faktor penting bagi personil di Kantor Polsek Semarang Tengah Kota Semarang karena akan sangat berpengaruh terhadap keberhasilan pengelolaan otonomi daerah. Sebagaimana ditegaskan dalam UU No. 32 Tahun 2004 diketahui bahwa dengan otonomi daerah tersebut, pemerintah daerah telah memperoleh kewenangan pengelolaan daerah bagi kepentingan daerah dan masyarakatnya sehingga 
konsekuensinya pemerintah daerah harus mampu memenuhi kepentingan masyarakat melalui pembangunan dan pelayanan umum yang lebih baik.

Salah satu tujuan pemberian otonomi daerah adalah dalam rangka peningkatan efektivitas dan efisiensi penyelenggaraan pemerintahan di daerah, terutama dalam hal pelaksanaan pembangunan dan pelayanan kepada masyarakat, sehingga diharapkan dapat meningkatkan kualitas pelayanan dan kesejahteraan rakyat. Aspek penting yang mempengaruhinya antara lain kenyataan mengenai tingkat kualitas sumber daya manusia dan kemampuan keuangan daerah yang dirasa masih kurang. Tetapi dari aspek-aspek tersebut kualitas sumber daya manusia, baik sumber daya manusia aparatur maupun masyarakat, merupakan faktor paling dominan terhadap pelaksanaan otonomi daerah, karena faktor-faktor lain secara empirik tergatung dari faktor ini. Berapapun besarnya dana yang dimiliki oleh suatu daerah, dan betapa besarnya sumber daya alam yang tersedia, tanpa sumber daya manusia yang berkualitas, maka akan sulit daerah tersebut untuk berkembang.

Keberhasilan pencapaian tujuan organisasi sangat dipengaruhi oleh peran dan kinerja para personilnya. Oleh sebab itu organisasi harus dapat memanfaatkan partisipasi anggota untuk menciptakan ketahanan dan kelangsungan hidup organisasi.

Personil Di kantor Polsek Semarang Tengah Kota Semarang dituntut untuk memperoleh dan memanfaatkan sumber daya yang ada untuk mencapai tujuannya. Beberapa kendala yang dihadapi Kantor Polres Kota Semarang adalah kendala dalam Kantor Polsek Semarang Tengah Kota Semarang itu sendiri mengenai buruknya kinerja SDM ditambah dengan menaungi beberapa kelurahan yang ada yang tersebar diseluruh wilayah Kota Semarang dari permasalah yang ada adalah: a. Masih rendahnya kinerja sumber daya manusia dalam melaksanakan tugasnya.

b. Tidak meratanya sumber daya manusia yang ada di Kantor Polres Kota Semarang.

c. Masih kurangnya tingkat disiplin di Kantor Polres Kota Semarang.

d. Adanya kendala waktu dalam berkoordinasi yang kurang baik antar Kantor Polres di Kota Semarang.

Dari uraian tersebut menggambarkan bahwa penyempurnaan di bidang manajemen sumber daya manusia yang terkait dengan peningkatan kinerja personil harus selalu mendapat perhatian, untuk mewujudkan personil

yang kompeten dengan berbagai pendekatan dan kebijaksanaan. Untuk itu, diperlukan adanya pembinaan, penyadaran, dan kemauan kerja yang tinggi untuk mencapai kinerja yang diharapkan dan harus didukung penuh kesadaran personil untuk bekerja secara optimal.

Meningkatkan kinerja personil dapat dilakukan dengan banyak cara, salah satunya dengan menerapkan disiplin kepada personilnya. Disiplin bagi personil merupakan hal yang sangat penting, karena disiplin merupakan usaha, tindakan dan kegiatan yang dilakukan oleh pimpinan untuk memperoleh kinerja personil yang baik. Apabila pimpinan menerapkan kedisiplinan yang tegas kepada personilnya, maka segala aktivitas yang ada dalam pelaksanaan pemerintahan dapat diselesaikan dengan cepat dan dapat memperoleh hasil yang lebih baik. Personil pun dapat bekerja sesuai dengan peraturan.

Di samping itu, adanya kesempatan untuk mengembangkan diri serta promosi sangat mendukung adanya peningkatan kinerja yang tinggi dalam organisasi. Mengingat promosi sering pula disebut kembalinya seorang personil ke posisi pekerjaan yang lebih tinggi. Promosi juga dikatakan sebagai kenaikan jabatan 
seorang personil ke jenjang yang lebih tinggi. Peningkatan kinerja personil, juga dipengaruhi oleh kompensasi. Seorang personil bekerja untuk memperoleh kompensasi guna memenuhi kebutuhan hidupnya. Pemberian kompensasi berupa finansial merupakan kebutuhan primer, karena finansial yang diterima oleh personil dapat menunjang kelangsungan hidupnya, oleh karena itu kebutuhan akan memperoleh kompensasi berupa finansial merupakan faktor pendorong yang kuat bagi personil untuk bekerja. Sehingga

pemberian kompensasi memiliki hubungan timbal balik, antara personil dengan organisasi. Personil sangat

mengharapkan kompensasi yang diberikan dari organisasi sesuai dengan pengorbanan yang dilakukannya, dan organisasi mengharapkan tersedianya personil yang cakap dan memenuhi syarat untuk suksesnya tujuan yang telah

ditetapkan. Jika organisasi memperhatikan pemberian kompensasi finansial yang mencukupi kepada

personilnya, maka personil akan menunjukkan kepuasan kerja yang baik, yang pada akhirnya dapat mencapai tujuan organisasi.

Berdasarkan uraian di atas, maka peneliti tertarik untuk melakukan penelitian dengan kajian: "Pengaruh Disiplin Kerja, Motivasi dan Kompensasi Terhadap Kinerja Personil Kantor Polsek Semarang Tengah Kota Semarang".

\section{Metode Penelitian}

Adapun penentuan jumlah sampel yang digunakan oleh penulis dalam penelitian ini adalah dengan metode sensus atau sampling jenuh berdasarkan pada ketentuan yang dikemukan oleh Sugiyono (2008) yang menyatakan bahwa: Samping Jenuh adalah teknik penentuan sampel bila semua anggota populasi dijadikan sampel, sehingga penelitiannya merupakan penelitian populasi. Jumlah sampel penelitian sebanyak 105 personil.

Analisa regresi, digunakan untuk melihat bagaimana pengaruh dari variable bebas terhadap variabel terikat. Dalam penelitian ini analisis regresi dilakukan dengan regresi langsung (untuk mengetahui pengaruh disiplin kerja, motivasi dan kompensasi terhadap kinerja personil).

$$
\begin{gathered}
\text { Model Matematis: } \\
\mathbf{Y}=\boldsymbol{\beta} \mathbf{1} \mathbf{X} \mathbf{1}+\boldsymbol{\beta} \mathbf{2} \mathbf{X} \mathbf{2}+\boldsymbol{\beta} \mathbf{3} \mathbf{3}
\end{gathered}
$$

Keterangan :

b1-3 = Koefisien Regresi

$\mathrm{X}_{1}=$ Variabel Disiplin Kerja

$\mathrm{X}_{2}=$ Variabel Motivasi

$\mathrm{X}_{3}=$ Variabel Kompensasi

$\mathrm{Y} \quad=$ Variabel Kinerja Personil

\section{Hasil dan Pembahasan}

Hasil penelitian menunjukkan bahwa terdapat pengaruh yang signifikan antara variabel disiplin kerja $\left(\mathrm{X}_{1}\right)$, motivasi kerja $\left(\mathrm{X}_{2}\right)$, dan kompensasi $\left(\mathrm{X}_{3}\right)$ terhadap kinerja personil (Y) di Polsek Semarang Tengah Kota Semarang, sehingga hipotesis yang diajukan dapat diterima.

\section{Pengaruh Disiplin Kerja Terhadap Kinerja Personil Di Polsek Semarang Tengah Kota Semarang}

Uji hipotesis 1 Hasil perhitungan menunjukkan bahwa terdapat pengaruh yang positif dan signifikan disiplin kerja terhadap kinerja personil. Hal ini didukung dengan koefisien regresi disiplin kerja sebesar 0,401 dengan tingkat signifikansi $0,000<0,05$, hal ini berarti terdapat pengaruh yang positif dan signifikan disiplin kerja terhadap kinerja personil. Hal ini berarti hipotesis pertama diterima. Dengan demikian disiplin kerja yang tinggi menentukan menigkatnya kinerja personil di Polsek Semarang Tengah Kota Semarang.

Berdasarkan hasil temuan di variabel disiplin kerja, diantara 4 dimensi 
yang diteliti, dimensi ketegasan merupakan dimensi yang paling berpengaruh terhadap kinerja personil dengan rata-rata dimensi yaitu sebesar 4,16. Hal ini menunjukkan bahwa setiap personil memiliki tanggapan yang positif dan setuju terhadap pernyataan yang berkaitan dengan dimensi ketegasan yang ada di Polsek Semarang Tengah Kota Semarang pada kenyataannya perlunya pemberian motivasi dan penegakan disiplin oleh pimpinan, serta adanya kontrak kerja dan perjanjian sebagai bentuk disiplin kerja yang harus di laksanakan, dan setiap pegawai mampu mempunyai komitmen kerja yang jelas dan berdampak peningkatan kinerja.

Disamping itu didukung adanya peningkatan kinerja personil melalui dimensi jumlah pekerjaan dengan ratarata dimensi sebesara 4,42. Hal ini menunjukan pada kenyataanya setiap pegawai mampu menyelesaikan pekerjaan tepat waktu, serta tidak ada pekerjaan yang menumpuk saat karyawan bekerja. Kondisi ini dapat meningkatakan mutu kinerja dimasa yang akan datang.

$$
\text { Dimensi yang berpengaruh }
$$

selanjutnya adalah dimensi keadaialan dan sangsi hukuman yang memiliki konstribusi rata-rata dimensi sebesar 4,14 yang berpengaruh terhadap kinerja personil. Hal ini menunjukan dari beberapa dimensi yang ada pada variabel disiplin kerja pada kenyataanya Adanya standar disiplin yang berlaku dalam lingkungan organisasi, serta Sifat sangsi yang diberikan kepada pegawai yang melanggar sesuai dengan presedur yang ada, maka dalam kondisi ini tetap harus ditingkatkan guna meningkatan mutu kinerja yang profesinalisme. Disamping itu ada satu dimensi pengawasan melekat merupakan dimensi yang paling rendah dengan kontribusi rata-rata dimensi sebesar 4,04. Hal ini menunjukan pada kenyataanya masih ada kritik saran mengenai masih ada beberapa pegawai belum patuh dan wajib atas peraturan yang sudah ditentukan, serta ada beberapa pegawai belum mampu melakukan pencegahan pelanggaran aturan. Kondisi ini yang dapat menurunkan kinerja pegawai, maka harus ditingkatkan guna memotivasi pegawai itu sendiri.

Disiplin kerja adalah suatu alat yang digunakan para manajer untuk berkomunikasi dengan pegawai agar mereka bersedia untuk mengubah suatu perilaku serta sebagai suatu upaya untuk meningkatkan kesadaran dan kesediaan seseorang mentaati semua peraturan perusahaan dan norma-norma sosial yang berlaku (Rivai, 2009). Sebagai contoh, beberapa pegawai biasa terlambat untuk bekerja, mengabaikan prosedur keselamatan kerja, melalaikan pekerjaan, melakukan tindakan yang tidak sopan, atau melakukan tindakan yang tidak pantas. Disiplin kerja memerlukan alat komunikasi, terutama pada peringatan yang bersifat spesifik terhadap pegawai yang tidak mau berubah sifat dan perilakunya.

Menurut Robbins (2003) bahwa kinerja adalah sebagai fungsi dari interaksi antara kemampuan dan motivasi. Dalam studi manajemen kinerja pekerja atau ada hal yang memerlukan pertimbangan yang penting, sebab kinerja individual seorang dalam organisasi merupakan bagian dari kinerja organisasi, dan dapat menentukan kinerja dari organisasi tersebut.

\section{Pengaruh Motivasi Kerja Terhadap Kinerja Personil Di Polsek Semarang Tengah Kota Semarang}

Uji hipotesis 2 Hasil perhitungan menunjukkan bahwa terdapat pengaruh yang positif dan signifikan motivasi kerja terhadap kinerja personil. Hal ini didukung dengan koefisien regresi motivasi kerja sebesar 0,334 dengan tingkat signifikansi $0,000<0,05$, hal ini berarti terdapat pengaruh yang positif dan signifikan motivasi kerja terhadap kinerja personil. Hal ini berarti hipotesis kedua 
diterima. Dengan demikian motivasi kerja yang tinggi menentukan meningkatnya kinerja personil di Polsek Semarang Tengah Kota Semarang .

Berdasarkan hasil temuan di variabel Motivasi kerja, diantara 5 dimensi yang diteliti, dimensi sosial dan kasih sayang merupakan dimensi yang paling berpengaruh terhadap kinerja personil dengan rata-rata dimensi yaitu sebesar 4,40. Hal ini menunjukan bahwa pada kenyataannya setiap personil mempunyai hubungan yang baik antara pimpinan dengan bawahan, serta Loyalitas saling memotivasi yang baik sesama pimpinan dan bawahan. Disamping itu didukung adanya peningkatan kinerja pegawai melalui dimensi jumlah pekerjaan dengan rata-rata dimensi sebesara 4,42. Hal ini menunjukan pada kenyataanya setiap pegawai mampu menyelesaikan pekerjaan tepat waktu, serta tidak ada pekerjaan yang menumpuk saat karyawan bekerja. Kondisi ini dapat meningkatakan mutu kinerja dimasa yang akan datang.

Dimensi yang berpengaruh selanjutnya adalah dimensi kebutuhan aktualisasi yang memiliki konstribusi rata-rata dimensi sebesar 4,33, sedangkan dimensi kebutuhan fisiologis dasar memiliki kontribusi rata-rata dimensi sebesar 4,32, dimensi kebutuhan pengharagaan memiliki kontribusi ratarata dimensi sebesar 4,22, yang mempengaruhi kinerja personil. Hal ini menunjukan dari beberapa dimensi dari variabel motivasi kerja bahwa kondisi kinerja pegawai sudah tergolong cukup baik, akan tetapi harus tetap ditingkatkan guna meningkatkan mutu kinerja yang profesionalisme di setiap bidangnya. Disamping itu ada satu dimensi keselamatan dan keamanan merupakan dimensi yang paling rendah dengan kontribusi rata-rata dimensi sebesar 4,02. Hal ini menunjukan pada kenyataanya masih ada kritik saran mengenai masih ada beberapa pegawai belum mendapatakan tunjungan hari tua untuk rasa aman, dan tunjangan kesehatan untuk rasa aman. Kondisi harus tetap ditingkatkan guna meningkatkan motivasi kerja dalam melaksanakan tugasnya serta berdampak pada peningkatan mutu kinerjanya.

Menurut Hasibuan (2007) motivasi kerja adalah pemberian daya penggerak yang menciptakan kegairahan kerja seseorang agar mereka mau bekerja sama, bekerja efektif dan terintegrasi dengan segala daya upayanya untuk mencapai kepuasan. Motivasi mempersoalkan bagaimana caranya mendorong gairah kerja bawahan, agar mereka mau bekerja keras dengan memberikan semua kemampuan dan keterampilannya untuk mewujudkan tujuan perusahaan. Sedangkan motivasi tersebut adalah daya pendorong yang mengakibatkan seorang anggota organisasi mau dan rela

waktunya untuk menyelenggarakan berbagai kegiatan yang menjadi tanggung jawabnya dan menunaikan kewajibannya dalam angka pencapaian tujuan dan berbagai sasaran organisasi yang ditentukan sebelumnya (Siagan 2007).

Nawawi (2005) menyatakan bahwa, "Kinerja adalah hasil pelaksanaan suatu pekerjaan, baik bersifat fisik/material maupun non fisik/non material". Mathis dan Jackson (2006) menyatakan bahwa, "Kinerja (performance) pada dasarnya adalah apa yang dilakukan atau tidak dilakukan oleh karyawan. Kinerja karyawan yang umum untuk kebanyakan pekerjaan meliputi elemen sebagai berikut: (1) kuantitas dari hasil, (2) kualitas dari hasil, (3) ketepatan waktu dari hasil, (4) kehadiran, dan (5) kemampuan bekerja sama.".

Pengaruh Kompensasi Terhadap

\section{Kinerja Personil Di Polsek Semarang} Tengah Kota Semarang

Uji hipotesis 3 Hasil perhitungan menunjukkan bahwa terdapat pengaruh yang positif dan signifikan kompensasi 
terhadap kinerja personil. Hal ini didukung dengan koefisien regresi kompensasi sebesar 0,266 dengan tingkat signifikansi $0,000<0,05$, hal ini berarti terdapat pengaruh yang positif dan signifikan kompensasi terhadap kinerja personil. Hal ini berarti hipotesis ketiga diterima. Dengan demikian kompensasi yang tinggi maka akan meningkatkan kinerja personil di Polsek Semarang Tengah Kota Semarang.

Berdasarkan hasil temuan di variabel kompensasi, diantara 2 dimensi yang diteliti, dimensi kompensasi financial merupakan dimensi yang paling berpengaruh terhadap kinerja personil dengan rata-rata dimensi yaitu sebesar 4,82. Hal ini menunjukkan bahwa setiap personil memiliki tanggapan yang positif dan sangat setuju terhadap pernyataan

yang berkaitan dengan dimensi kompensasi financial yang diberikan kepada personil yang berprestasi di

Polsek Semarang Tengah pada kenyataanya gaji yang diberikan pihak manajemen kepada setiap pegawai sudah sesuai harapan, serta tunjangan yang diberikan kepada setiap pegawai pada saat hari raya sudah sesuai harapan, dan pihak manajemen memberikan insentif kepada

pegawai yang berprestasi kerja.

Disamping itu didukung adanya peningkatan kinerja pegawai melalui dimensi jumlah pekerjaan dengan ratarata dimensi sebesara 4,42. Hal ini menunjukan pada kenyataanya setiap pegawai mampu menyelesaikan pekerjaan tepat waktu, serta tidak ada pekerjaan yang menumpuk saat karyawan bekerja. Kondisi ini dapat meningkatakan mutu kinerja dimasa yang akan dating.

Dimensi yang berpengaruh selanjutnya adalah dimensi kompensasi non-financial merupakan dimensi yang paling rendah dengan kontribusi rata-rata dimensi sebesar 4,39. Hal ini menunjukan pada kenyataanya masih ada kritik saran mengenai masih ada beberapa pihak manajemen kantor memberikan pengahargaan kepada karyawan atas hasil kerjanya, jenjang karir yang diberikan kepada setiap pegawai jelas dan berkesinambungan di masa depan, dan pihak manajemen kantor memberikan pelatihan terhadap karyawanya yang kinerjanya masih rendah. Kondisi kompensasi yang ada dilingkungan organisasi di Polsek Semarang Tengah Sudah tergolong sangat baik, akan tetapi harus tetap ditingkatakan guna meningkat mutu kinerjanya.

Menurut Rivai (2009) gaji adalah balasan jasa dalam bentuk uang yang diterima pegawai sebagai konsekuensi dari statusnya sebagai seorang pegawai yang memberikan kontribusi dalam mencapai tujuan perusahaan. Atau, dapat juga dikatakan sebagai bayaran tetap yang diterima seseorang karena kedudukannya dalam perusahaan. Menurut Sikula (dalam Hasibuan, 2007), gaji adalah segala sesuatu yang dikonstitusikan atau dianggap sebagai suatu balas jasa atau ekuivalen. Dari pendapat ahli mengenai kompensasi, maka dapat disimpulkan, bahwa kompensasi adalah pemberian imbalan yang berbentuk uang yang diterima secara langsung oleh karyawan sebagai imbalan atas pekerjaannya selama satu periode. Russel (2003) mengemukakan bahwa kinerja sebagai catatan keberhasilan yang dihasilkan dari fungsi suatu pekerjaan tertentu/kegiatan selama periode tertentu. Menurutnya ada enam kategori untuk mengukur kinerja pegawai, yaitu: kualitas, kuantitas, ketepatan waktu, efektifitas, kemandirian dan komitmen. sedangkan Byors dan Rue (2006) kinerja merupakan derajat penyelesaian tugas yang menyertai pekerjaan seseorang yang seberapa baik individu memenuhi permintaan pekerjaan.

Pengaruh Disiplin Kerja, Motivasi Kerja, Dan Kompensasi Secara Bersama-sama Terhadap Kinerja Personil Di Polsek Semarang Tengah Kota Semarang 
Uji hipotesis 4 Hasil penelitian menunjukkan bahwa terdapat pengaruh yang positif dan signifikan disiplin kerja, motivasi kerja, dan kompensasi secara bersama-sama terhadap kinerja personil di Polsek Semarang Tengah Kota Semarang. $\mathrm{Hal}$ ini diperkuat dengan nilai $\mathrm{F}$ hitung $>$ F tabel, yaitu sebesar 57, $681>2,69$, jadi simpulannya Ha diterima dan Ho ditolak, berarti ada pengaruh positif dan signifikan variabel disiplin kerja, motivasi kerja, dan kompensasi secara bersama-sama terhadap kinerja pegawai. Dengan demikian semakin baik disiplin kerja, motivasi kerja, kompensasi yang baik maka setiap akan merasa puas dan termotivasi untuk menignkatkan mutu kinerja di masa yang akan datang.

Berdasarkan hasil perhitungan variabel disiplin kerja, motivasi dan kompensasi, diantara 3 variabel yang diteliti. variabel komepensasi dari dimensi kompensasi financial merupakan komponen yang paling berpengaruh terhadap kinerja personil yaitu dengan rata-rata dimensi sebesar 4,82. Sedangkan variabel motivasi kerja dengan dimensi kebutuhan sosial dan kasiah sayang berpengaruh dengan rata-rata dimensi sebesar 4,40, dan variabel disiplin kerja melalui dimensi ketegasan dengan ratarata dimensi sebesar 4,16 merupakan faktor penentu meningkatkan kinerja personil selanjutnya. Variabel yang paling berpengaruh terhadap kinerja personil di Polsek Semarang Tengah Kota Semarang adalah variabel disipli kerja. Hal ini berarti hipotesis yang menyatakan bahwa variabel disiplin kerja paling besar berpengaruh terhadap kinerja personil di Polsek Semarang Tengah Kota Semarang diterima. Hal ini ditunjukkan dengan nilai koefisien regresi sebesar variabel disiplin kerja sebesar $0,401>$ dibandingkan dengan motivasi kerja sebesar 0,334 , dan variabel kompensasi sebesar 0,266. Menurut Robbins (2003) bahwa kinerja adalah sebagai fungsi dari interaksi antara kemampuan dan motivasi. Dalam studi manajemen kinerja pekerja atau ada hal yang memerlukan pertimbangan yang penting, sebab kinerja individual seorang dalam organisasi merupakan bagian dari kinerja organisasi, dan dapat menentukan kinerja dari organisasi tersebut. Berhasil tidaknya kinerja yang telah dicapai organisasi tersebut, akan dipengaruhi oleh tingkat kinerja dari secara individu maupun kelompok.

\section{Kesimpulan}

Berdasarkan hasil penelitian, analisis data, dan pengujian hipotesis yang telah dilakukan, maka dapat ditarik kesimpulan sebagai berikut:

a. Ada pengaruh positif dan signifikan disiplin kerja terhadap kinerja personil di Polsek Semarang Tengah Kota Semarang, semakin tinggi tingkat disiplin kerja yang dimiliki oleh seorang personil, maka akan menigkatkan mutu kinerjanya.

b. Ada pengaruh positif dan signifikan motivasi kerja terhadap kinerja personil di Polsek Semarang Tengah Kota Semarang, semakin tinggi pemberian motivasi kerja terhadap personil, maka akan meningkatkan mutu kinerjanya.

c. Ada pengaruh positif dan signifikan kompensasi terhadap kinerja personil di Polsek Semarang Tengah Kota Semarang, semakin tinggi kompensasi yang diberikan kepada seorang personil, maka akan menigkatkan mutu kinerjanya.

d. Ada pengaruh positif dan signifikan insentif, pelatihan, dan disiplin kerja secara bersama-sama terhadap kinerja personil di Polsek Semarang Tengah Kota Semarang.

e. Variabel disiplin kerja paling besar pengaruhnya terhadap kinerja personil dibandingkan motivasi kerja, dan kompensasi di Polsek Semarang Tengah Kota Semarang. 


\section{DAFTAR PUSTAKA}

Arikunto, Suharsimi. 2006.Prosedur Penelitian Suatu Pendekatan Praktek. Jakarta : Rineka Cipta.

Alex, S, Nitisemito. 2005. Manajemen Personalia (Manajemen Sumber Daya Manusia, Edisi Kelima, Cetakan Keempat belas, Ghalia Indonesia, Jakarta

2001. Manajemen

Personalia. Ghalia Indonesia, Jakarta. .2000. "Manajemen

Personalia"Cetakan Ke-7. Ghalia Indonesia, Jakarta.

Byars, Llloyd L dan Rue, Leslie W. 2006. Human Resource Management, 8 edition. MCGraw-Hill, Irwin

Daft, Richard.L, 2007. Manajemen Edisi 6 Jakarta: PT. Salemba Empat. Gomes, F. Cardoso. 2006. Manajeman sumber daya manusia. Yogyakarta: Andi Offset.

Griffin, Jill. 2004. Customer Loyalty :Menumbuhkan Dan Mempertahankan Pelanggan. Jakarta, Airlangga.

Hadari, Nawawi. 2005. Metode Penelitian Bidang Sosial. Yogyakarta: Gadjah Mada University Press.

Handoko TH. 2003.

Manajemen Personalia

dan SDM. Edisi 2.

Yogyakarta: BPFE

Hasibuan, Malayu, S.P. 2007. Manajemen Dasar, Pengertian dan

Masalah. Jakarta : PT Toko Gunung Agung.

Hasibuan, Malayu S.P. 2010. Organisasi dan Motivasi Dasar

Peningkatan Produktivitas. Jakarta: PT Bumi Aksara.

Ghozali, H. Imam. 2006. Aplikasi Analisis

Multivariat Dengan Program SPSS. Semarang: Badan Penerbit UNDIP.
Kristianto. 2005.Perancangan

Sistem Kebijakan Perawatan yang Optimal berdasarkan RCM II (Studi Kasus PT Philips Indonesia)

Long, Barbara C. 2008. Perawatan Medikal Bedah (Suatu Pendekatan Proses Keperawatan) Jilid 3. Bandung : Yayasan Ikatan Alumni Pendidikan Keperawatan.

Luthans, F. 2006. Organizationanal Behavior, 9th ed. New York : McGraw-Hill Irwi

Mathis, Robert L. dan John H. Jackson. 2006. Manajemen Sumber Daya Manusia, Edisi Pertama Salemba Empat, Jakarta.

Robbin, P.Stephen. 2003. Perilaku Organisasi, Jilid I. Terjemahan Handyana Pudja Atmaka. Jakarta :Prenhallindo.

Robbins, S. P. 2006. Konsep Dasar dan Teknik Supervisi Pendidikan. Jakarta.Rineka Cipta.

Robert L. Mathis \& John H. Jackson, 2006. Human Resources

Management, Edisi sepuluh, Penerbit Salemba Empat.

Setiyawan, Budi dan Waridin. 2006. Pengaruh Disiplin Kerja Karyawan Dan Budaya Organisasi Terhadap Kinerja Di Divisi Radiologi RSUP Dokter Kariadi Semarang. JRBI. Vol 2. No 2. Hal: 181-198.

Sunyoto, Danang. 2013. Teori, kuisener, dan Proses Analisis data perilaku Organisasional. Yogyakarta :

Siagan, S. P. 2007. Manajeman sumber daya manusia. Jakarta: Bumi Aksara

Suwatno dan Donni Juni Priansa, 2011, Manajemen Sumber Daya Manusia, Bandung: Alfabeta.

Thoha, Miftah. 2009. Perilaku Organisasi Konsep Dasar dan Aplikasinya. Jakarta: Rajawali Grafindo Persada.

Tjiptono, Fandy. 2008. Strategi Pemasaran, Edisi Ketiga. Yogyakarta: Andi 